\title{
PECULARITIES OF PARENTAL ATTITUDE TOWARDS CHILDREN WITH PSYCHOPHYSICAL DEVELOPMENT DISORDERS
}

УДК 37.035.06-055.52:159.97-053.5 DOI https://doi.org/10.32843/26635208.2020.16.31

\section{Субашкевич I.P.}

к.психол.н., доцент кафредри

спеціальної освіти та соціальної роботи Львівський національний університет імені Івана Франка

\section{Вантух К.В.}

магістр факультету педагогічної освіти Львівський національний університет імені Івана Франка у статті висвітлено проблему батьківського ставлення до дітей з порушеннями психосрізичного розвитку. Описано поняття «батьківське ставлення», під яким розуміється система різноманітних почуттів $i$ вчинків дорослого по відношенню до дитини з вадами психофбізичного розвитку (інтегроване емоційне прийняття або відторгнення дитини, міжособистісна дистанція у спілкуванні з нею, форма і напрямок контролю за поведінкою). Охарактеризовано структурні компоненти ставлення батьків до дітей Виділено типи батьківського ставлення до неповносправних дітей та дітей із нормо-типовим розвитком. Також визначається важливість позитивного ставлення батьків до дитини з порушеннями психосрізичного розвитку. Висвітлено та проаналізовано результати дослідження, в яких брали участь батьки, що виховують дітей із порушеннями психоррізичного розвитку (до них увійшли сім'і, у яких $є$ діти з дитячим черебральним паралічем (ДЦП), із синдромом Дауна, із затримкою психічного розвитку - (ЗПР), та сім'ї, що мають дітей із нормо-типовим розвитком).

Відповідно до поставленої мети було підібрано «Методику діагностики батьківського ставлення», авторами якої є А. Варга i В. Столін. Ця методика дає можливість встановити домінуючий тип батьківського ставлення.Отримані результати дослідження дали змогу встановити домінуючий тип батьківського ставлення у сім'ях що виховують дитинуз особливими потребами. Батьківське ставлення є одним із складових дитячо-батьківських відносин. Воно є важливим у розвитку дитини. Для адекватного розвитку дитини з особливими потребами необхідно створити емоційно придатну $i$ стабільну ситуацію вдома. Створити таке середовище, у якому дитина почувала б себе потрібною та люблячою.

Ключові слова: батьківське ставлення, психосрізичний розвиток, неповносправна дитина, обмежені можливості, дитячо-батьківські відносини.

The article highlights the problem of parental attitudes towards children with psychophysical developmental disorders. The concept of "parental attitude" is described as a system of various feelings and actions of the adult towards the child with psychophysical development disorders (integrated emotional acceptance or rejection of a child, interpersonal distance in communication with a child, the form and direction of behavioral control). The structural components of the attitude of parents to children are characterized. The types of parental attitude towards special needs children and children with normotype development have been identified. The importance of parents' positive attitude towards children with psychophysical development disorders is also determined. The results of studies in which parents raising children with impaired psychophysical development took part (these include families in which there are children with cerebral palsy (ICP), with Down's syndrome, with mental retardation (MR) and families with children with normotype development) were covered and analyzed.

In accordance with target goal, the "Methodology of Diagnostics of Parental Attitude" was selected, authored by A. Varha and V. Stolin. This method makes it possible to establish the dominant type of parenting attitude. The obtained results of the study made it possible to establish the dominant type of parental attitude in families raising a child with special needs. The parenting attitude is one of the components of the parent-child relationship. It is important in a child's development. For the adequate development of a child with special needs, it is necessary to create an emotionally suitable and stable situation at home. To create an environment in which the child feels needed and loved.

Key words: parental attitude, psychophysical development, special needs child, parent-child relationship.
Постановка проблеми. Поява у сім'ї дитини з порушенями психофізичного розвитку стає стресом для її батьків. Найчастіше це вимагає переосмислення сімейних обов'язків та відносин. Батьки стикаються з питанням «Як виховувати таку дитину?». Слід зауважити, що про виховання дитини з нормо-типовим розвитком написано багато книжок та журналів. Про виховання дитини з порушеннями психофізичного розвитку інформацію знайти дуже важко. Батьки розгублені і не знають, як діяти і жити далі.

Через народження дитини з порушенями психофізичного розвитку стосунки у сім'ї, а також контакти із соціумом набувають викривленого характеру. Причини деформації пов'язані з психологічними особливостями стану дитини, а також зі значним психологічним навантаженням, що несуть члени родини у зв'язку із тривалою дією психотравмуючого стресу [3, с. 165]. Як наслідок, назрівають серйозні проблеми в сімейних відносинах та ставленні до їхньої дитини. У подальшому такі проблеми можуть призвести до неприйняття своєї дитини, гіперопіки або ж інфантилізації у вихованні.

Проблема впливу батьківського ставлення на розвиток дитини з порушеним психофізич- 
ним розвитком протягом довгого проміжку часу не знаходилась в осередку досліджень. у країнах Західного світу це питання стало актуальним у 60-х роках XX ст. Так, ця проблема прослідковується в роботах A. Dearling, P. Barham, R. Hayward M. Darling, D. Johnson. Уперіод Радянського Союзупроблеми, з якими стикались сім'ї, що мають дітей з обмеженими можливостями, розкрито у працях таких науковців, як: $Є$. Тиха (формування самосвідомості батьків, які переживають психотравмуючу ситуацію), Л. Шипіцина (взаємини в родинах, де виховуються діти з розумовою відсталістю; особистісні особливості матерів, що виховують дітей з розумовою відсталістю), Є. Ейдеміллер, В. Юстицький (структурно-функціональні особливості сімей із психічно хворим; основні напрямки розвитку сім'ї психічно хворого), В. Вишневський, Р. Майрамян (поява в батьків, які виховують особливу дитину, різних соматичних захворювань, астенічних та вегетативних розладів, депресивної симптоматики), В. Ткачова (виникнення в батьків дітей-інвалідів особистісних порушень, певних характерологічних рис особистості), І. Іванова (соціально-психологічні проблеми родин) [1].

У випадку виникнення в дитини тих чи інших порушень значну роль в її розвитку відіграють оточуючі його люди, які складають частину його маленького світу. Головне місце в цьому світі займають найрідніші люди - це мама і тато. Для адекватного розвитку дитини з порушеннями психофізичного розвитку необхідно створити емоційно придатну і стабільну ситуацію вдома. Створити таке середовище, у якому дитина почувала себе потрібною та люблячою.

Аналіз останніх досліджень і публікацій. Дослідженням питання проблем, з якими стикаються сім'ї дітей із порушеним психофізичним розвитком, займались такі науковці: Б. Андрейко, О. Ферт, О. Абрамова, Т. Вісковатова, Н. Подгорільська. Переважно об'єктом їхнього вивчення були діти та сім'ї з очевидним порушеним психофізичним розвитком. М. Радченко досліджував проблеми сімей, де виховувалась дитина з розумовою відсталістю. Т. Добровольська, І. Мамайчук, В. Мартинов вивчали проблеми сім'ї, де була дитина з дитячим церебральним паралічем (ДЦП). Науковці К. Островська та Д. Шульженко досліджувала сім'ї, що виховують дітей із розладами спектру аутизму (РСА). О. Романчук вивчав сім'ї, де була дитина із гіперактивним розладом із дефіцитом уваги (ГРДУ). Здебільшого науковці зосереджувались на аналізі та стадіях переживання батьками стресової ситуації, зумовленої народженням дитини з порушеним психофізичним розвитком. Набагато менше було досліджено психотравмуючий вплив виховання дитини з обмеженими можливостями, своєрідності функціонування в сім'ї [3, с. 22].
Сім'я, яка має дитину з порушеннями психофізичного розвитку, зіштовхується з великою кількістю проблем. Зважаючи на це в батьків страждає психологічне здоров'я. У нашій державі таким сім'ям допомагають лише приватні установи. Проте не всі можуть собі дозволити цю допомогу. Більшість батьків все-таки нікуди не звертаються за психологічною підтримкою. Отже, це може призвести до негативних наслідків, які потім відобразяться на розвитку дитини. Сім'я є тим важливим «фундаментом», де закладаються основи і навички, які необхідні дитині для її майбутнього. Для того, аби був міцний фундамент, дитина має відчувати, що її люблять та розуміють.

Постановка завдання. Головною метою цієї роботи $є$ висвітлення особливостей впливу батьківського ставлення на розвиток дитини з порушеннями психофізичного розвитку. Зокрема, розглянути та проаналізувати типи батьківського ставлення, які притаманні батькам дітей із з порушеннями психофізичного розвитку. Порівняти та дізнатися, чи існує різниця батьківського ставленнядо дітей із порушенням психофізичного розвитку та дітей із нормо-типовим розвитком.

Виклад основного матеріалу дослідження. Із метою визначення особливостей батьківського ставлення до дітей з обмеженими можливостями було використано тест-опитувальник «Батьківського ставлення» А. Варги та В. Століна. Батьківське ставлення - це цілісна система різноманітних почуттів до дитини, поведінкових стереотипів, що практикуються у спілкуванні з нею, особливостей сприйняття і розуміння характеру й властивостей дитини, її вчинків [4, с. 144]. Із психологічної точки зору батьківське ставлення - це педагогічна соціальна установка по відношенню до дітей, що включає в себе раціональний, емоційний і поведінковий компоненти. Один із позитивних та сприятливих типів батьківського ставлення, за А. Варга і В. Столін, - це прийняття дитини.

у структурі батьківського ставлення виокремлюють три складових частини: інтегроване емоційне прийняття або відторгнення дитини, міжособистісну дистанція у спілкуванні з нею, форму і напрямок контролю за поведінкою. Кожний вимір батьківського ставлення можна розглядати як співвідношення в різній пропорції емоційного, когнітивного й поведінкового компонентів. Становлення певного типу батьківського ставлення детермінують риси й особистісні якості батьків, фізичні, психологічні і статеві особливості дитини, особливості подружніх взаємин, соціокультурні фактори, сімейні традиції, етологічний фактор [2, с. 12]

Слід зазначити, що емоційне ставлення батьків до дитини єфундаметном, який закладає підґрунтя для її подальшого розвитку. 
Дослідження проведено в 2020 році із використанням гугл-платформи. В опитуванні всього взяло участь 20 сімей, із них - 10 сімей, які виховують дітей із порушеннями психофізичного розвитку, та 10 сімей, які мають дітей із нормо-типовим розвитком. Опитані з обох груп виховували дітей дошкільного віку. Вік опитаних батьків - від 22 до 44 років.

Згідно 3 результатами дослідження за тестом-опитувальником «Батьківського ставлення» А. Варги та В. Століна (рис. 1) високого рівня за типом батьківського ставлення «Прийняття-відторгнення» не було зафіксовано в жодній з груп. У $90 \%$ сімей із дітьми з порушеннями психофізичного розвитку - середні результати. А у $100 \%$ сімей, що виховують дітей із нормо-типовим розвитком, - середні результати. Низькі показники виявлено у $10 \%$ сімей, що мають дітей із порушеннями психофізичного розвитку. Проте в батьків із дітьми з нормо-типовим розвитком не виявлено низьких показників даного типу батьківського ставлення.

Середній рівень показників за шкалою «прийняття-відторгнення» свідчить, що дорослий, з одного боку, приймає дитину такою, яка вона $€$, поважає і визнає ії індивідуальність, схвалює ії інтереси, підтримує плани. Він проводить із ним досить багато часу і не шкодує про це. При цьому відчуває позитивні емоції. А з іншого боку - байдужість. Низький рівень виявляє те, що дорослий відчуває по відношенню до дитини в основному негативні почуття: роздратування, злість, досаду, ненависть. Такий дорослий вважає дитину невдахою, не вірить в його майбутне, низько оцінюе його здібності і нерідко нехтує дитиною. Зрозуміло, що з такими нахилами дорослий не може бути хорошим педагогом.
За результатами дослідження за типом батьківського ставлення «Соціально-бажаний образ (кооперація)» (рис. 2) високий рівень показали $80 \%$ сімей, у яких $є$ діти 3 порушеннями психофізичного розвитку. 70\% сімей із дітьми з нормо-типовим розвитком показали високий результат. Середні показники виявлено у $20 \%$ сімей із дітьми з порушеннями психофізичного розвитку. У $30 \%$ сімей із дітьми з нормо-типовим розвитком зафіксовано середній рівень. Низькі результати за цим типом ставлення не виявлено в жодній із груп.

Високий рівень вказуе на те, що дорослий виявляє зацікавленість у справах і планах дитини. Він високо оцінює інтелектуальні і творчі здібності дитини та заохочує самостійність і ініціативу дитини, намагається бути з нею на рівних. Дорослий намагається у всьому допомогти дитині та співчуває їй. Відчуває почуття гордості за свою дитину. Батьки довіряють дитині, намагаються погодитись із її точкою зору у спірних питаннях.

За результатами дослідження типу батьківського ставлення «симбіоз» (рис. 3), високі результати показали $30 \%$ сімей із дітьми з порушеннями психофізичного розвитку. 30\% сімей $з$ дітьми з нормо-типовим розвитком теж показали високі результати. У $60 \%$ сімей із дітьми з порушеннями психофізичного розвитку виявлено середній рівень. 30\% сімей, які мають дітей із нормо-типовим розвитком, показали середні результати. Низький рівень виявлено у $10 \%$ сімей із дітьми з порушеннями психофізичного розвитку, та у $30 \%$ сімей - із дітьми з нормо-типовим розвитком.

Високі бали цього типу батьківського ставлення свідчать про те, що доросла людина не

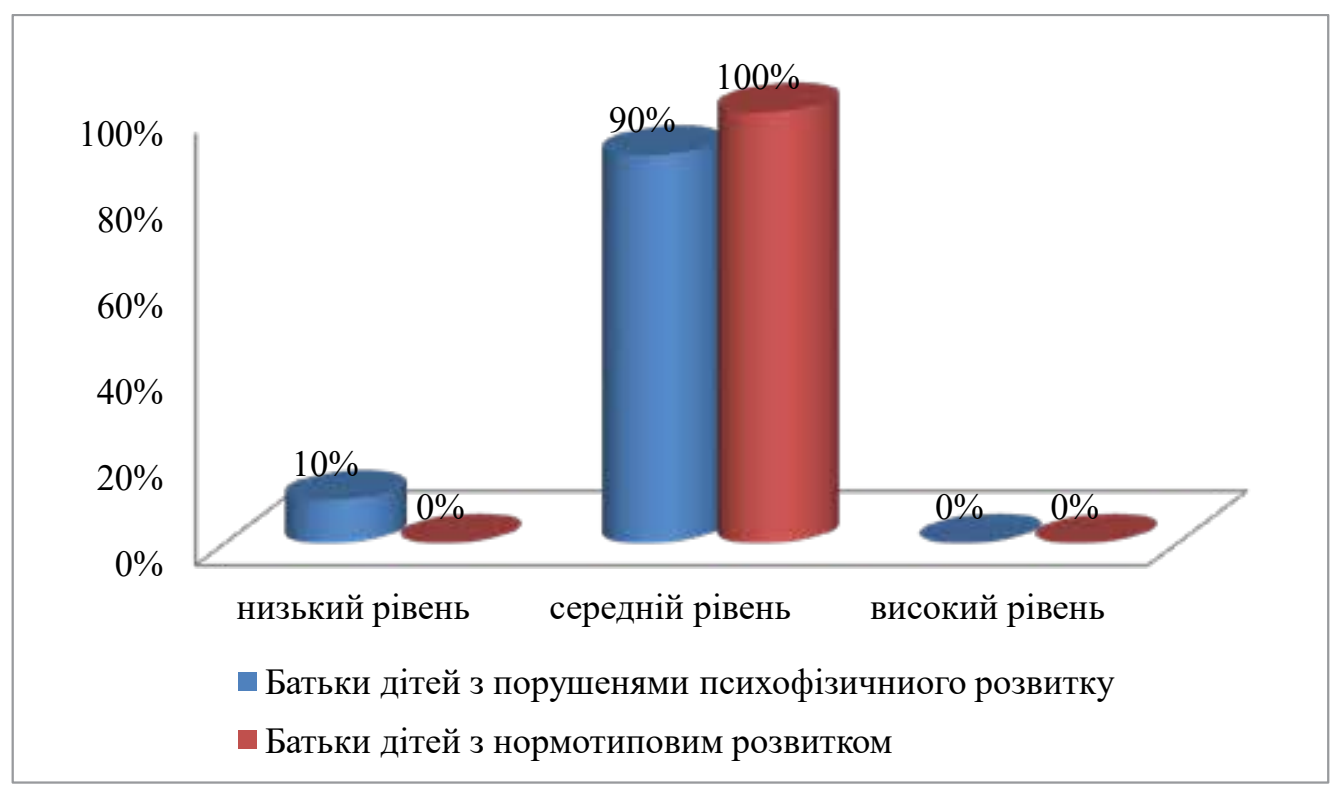

Рис. 1. Прийняття-відторгнення(у \%) 


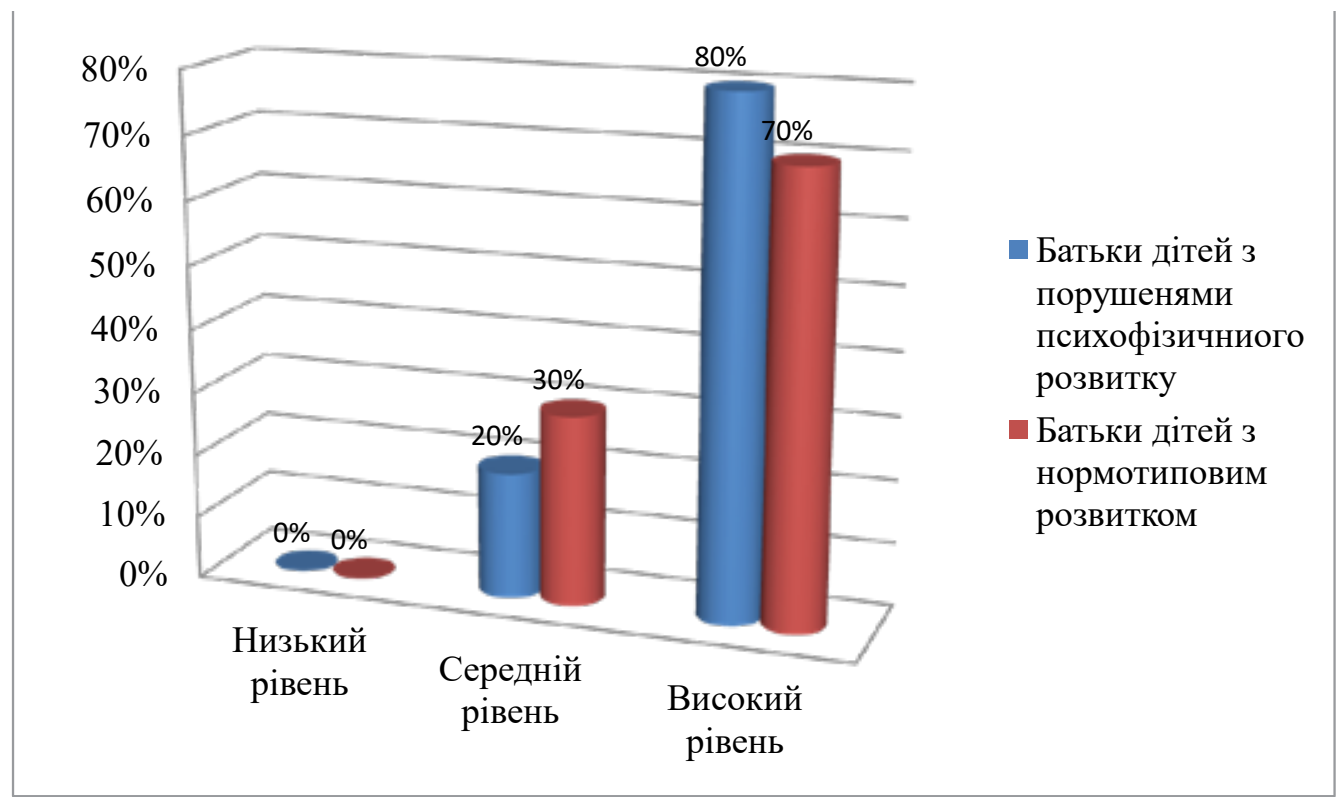

Рис. 2. Соціально-бажаний образ (кооперація) (у \%)

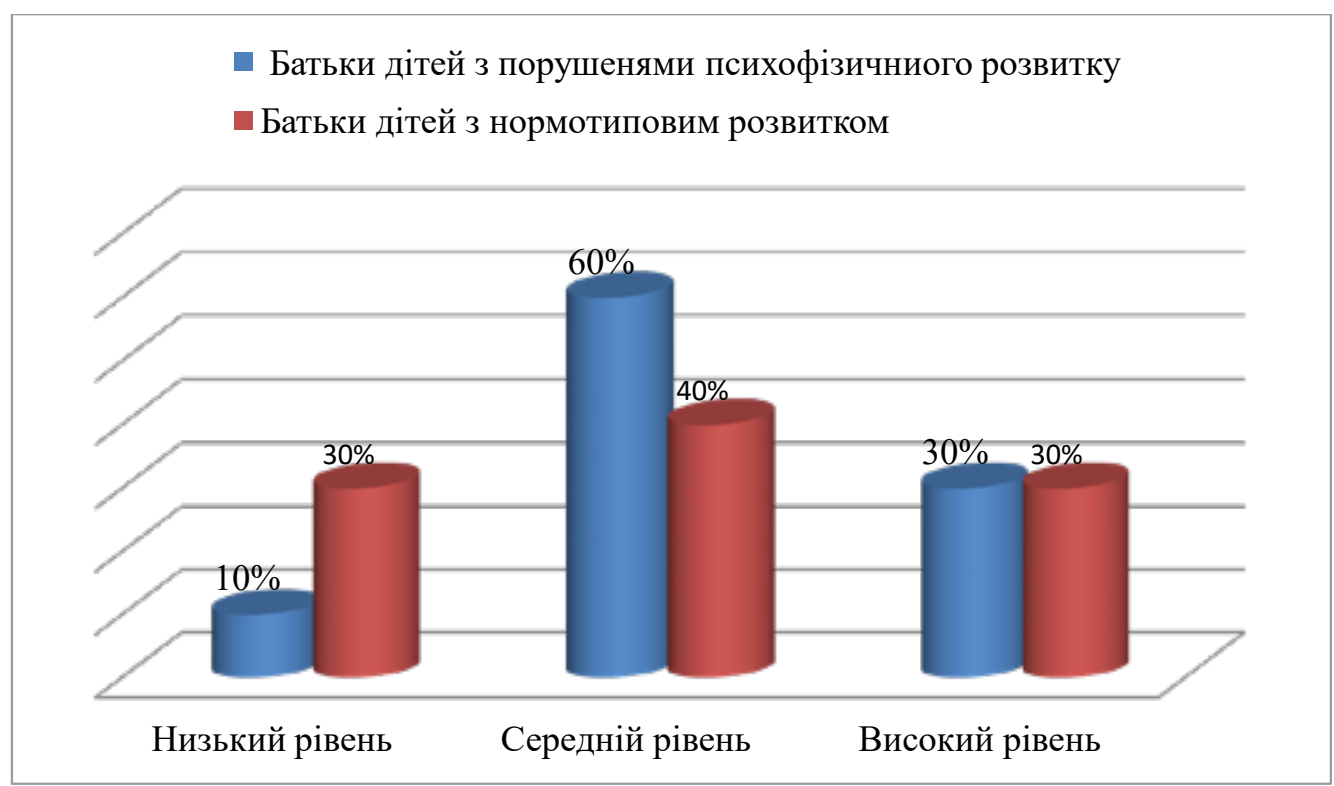

Рис. 3. Симбіоз

встановлює психологічну дистанцію між собою і дитиною та намагається завжди бути ближче до неї. Також задовольняє її основні розумні потреби, захищає від труднощів та неприємностей. Батьки відчувають себе з дитиною єдиним цілим та відчувають тривогу за неї. Тривога підвищується, коли дитина стає автономною, оскільки батьки обмежують їі самостійність. Зазвичай дитина для батьків здається маленькою і беззахисною. Низькі результати ознака того, що дорослий, навпаки, встановлює значну психологічну дистанцію між собою і дитиною, мало про неї піклується. Навряд чи такий дорослий може бути хорошим учителем і вихователем для дитини.
Високі результати за типом батьківського ставлення «авторитарна гіперсоціалізація» (рис. 4) показали 10\% батьків, які виховують дітей із нормо-типовим розвитком. Проте серед сімей, які мають дитину з порушеннями психофізичного розвитку, високих показників за цим типом батьківського ставлення не виявлено (0\%). Середні результати виявлено у $60 \%$ сімей, які мають дітей із порушеннями психофізичного розвитку; та $40 \%$ сімей, які виховують дітей із нормо-типовим розвитком. Низькі результати показали $40 \%$ сімей із дітьми з порушеннями психофізичного розвитку та 30\% сімей із дітьми з нормо-типовим розвитком. 


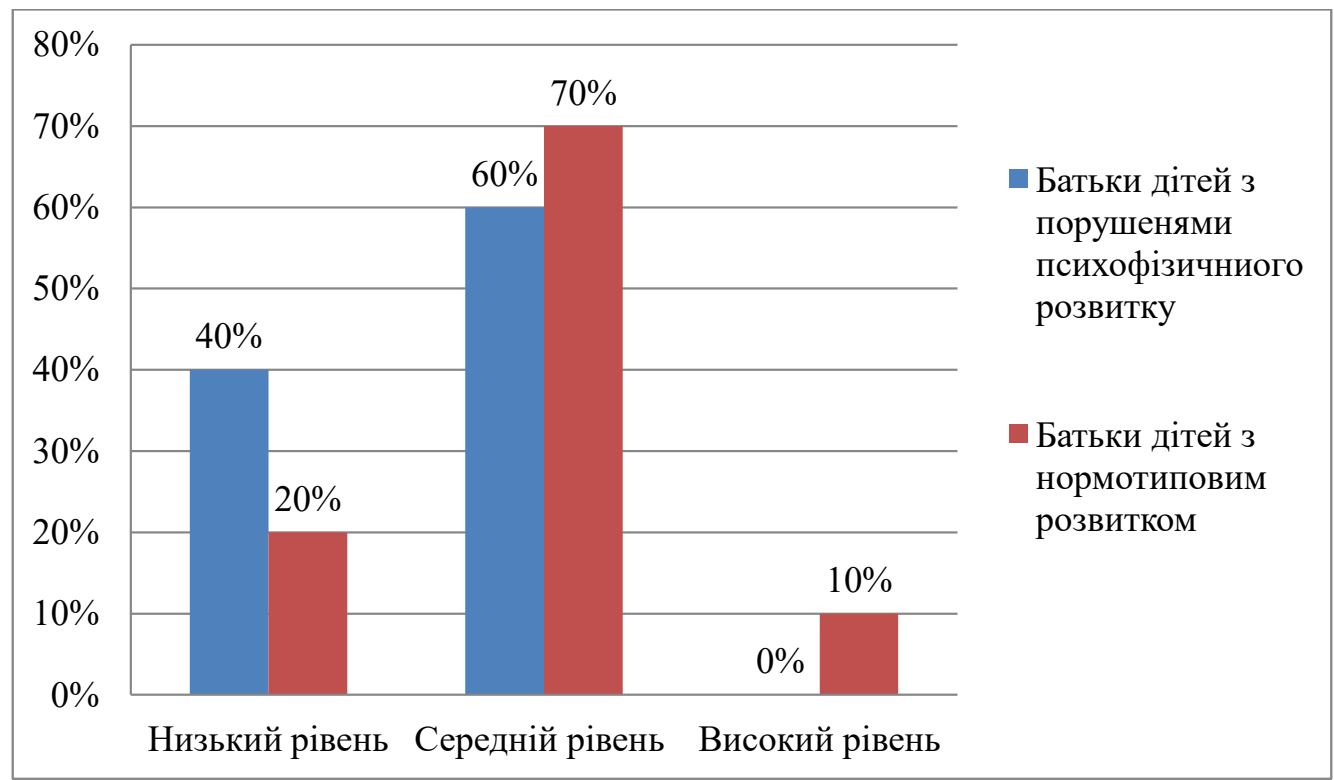

Рис. 4. Авторитарна гіперсоціалізація (у \%)

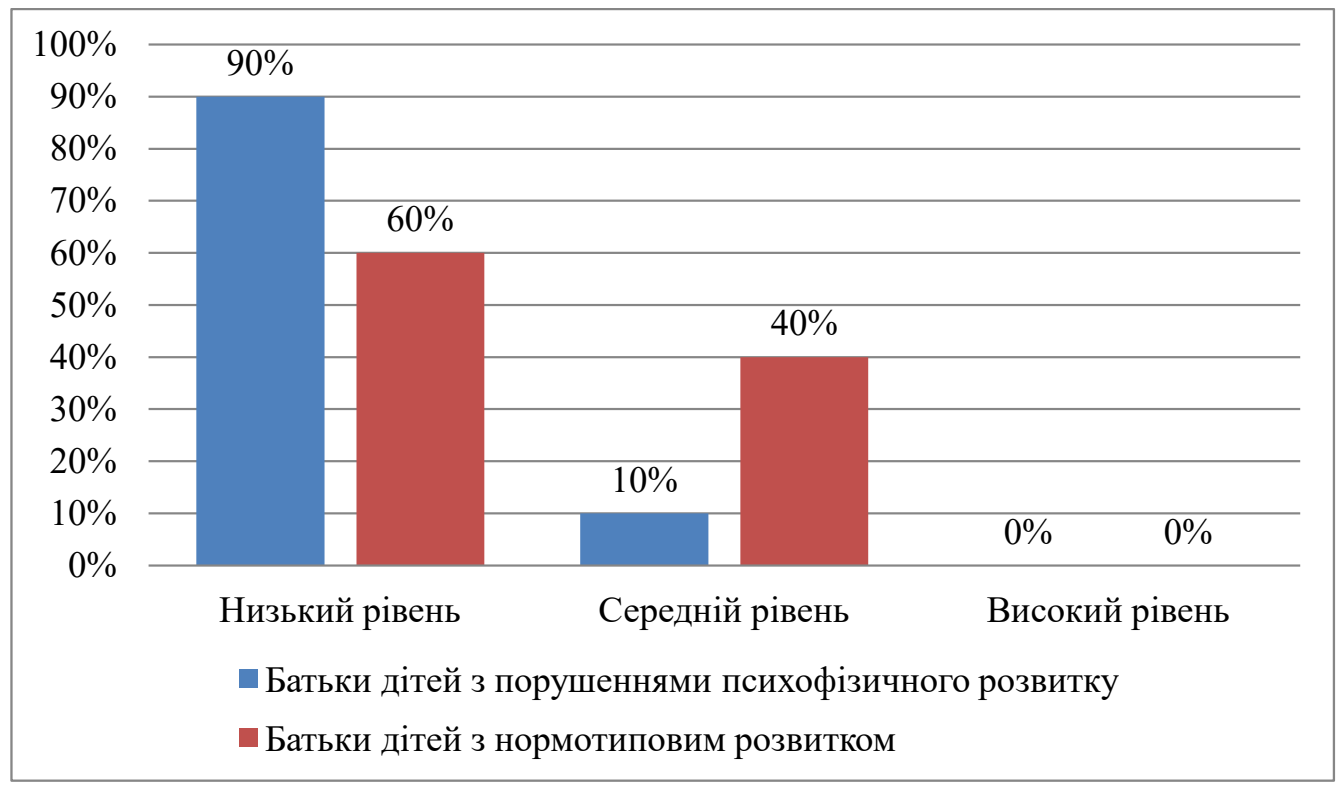

Рис. 5. Інфантилізація (у \%)

Високі бали за цим типом батьківського ставлення показують те, що доросла людина поводить себе занадто авторитарно по відношенню до дитини. Вона вимагає від нього беззастережного послуху і дисципліни. Дорослий створює дитині суворі дисциплінарні рамки. Він нав'язує дитині майже в усьому свою волю, не в змозі стати на його точку зору. Слід зауважити, що за явища свавілля дитину суворо карають. Також дорослий пильно стежить за соціальними досягненнями дитини, її індивідуальними особливостями, звичками, думками, почуттями. Батьки, які набрали середні бали, мають добре розвинені педагогічні здібності і добре знають, де «золота середина» у вихо- ванні своєї дитини. Низькі результати свідчать про те, що контроль над діями дитини з боку дорослого практично відсутній. Проте це не дуже добре для навчання і виховання дітей.

За результатами опитування щодо типу батьківського ставлення «інфантилізація» (рис. 5) високих балів не виявлено в жодній групі досліджуваних. 40\% сімей, які виховують дітей із нормо-типовим розвитком, показали середні результати. $10 \%$ сімей, що мають дітей із порушеннями психофізичного розвитку, теж показали середні результати. 60\% сімей із дітьми з нормо-типовим розвитком показали низькі результати. 90\% сімей із дітьми з порушеннями психофізичного розвитку показали низький результат. 
Низькі бали за цим типом батьківського ставлення свідчать про те, що невдачі дитини дорослий вважає випадковими і вірить в нього. Такий дорослий, швидше за все, стане непоганим учителем і вихователем.

Отже, в батьків, які мають дітей із порушеннями психофізичного розвитку, переважає високий рівень кооперації, середній рівень симбіозу та авторитарної гіперсоціалізації. Також низький рівень по типу батьківського ставлення «інфантилізація». 3 огляду на це батьки виявляють зацікавленість у справах і планах дитини, допомагають ій та співчувають. На нашу думку, такі батьки є добрими педагогами для свої дітей.

Згідно з методикою «Методика діагностики батьківського ставлення», авторами якої $€$ А. Варга і В. Столін, можна встановити домінуючий тип батьківського ставлення. Високі бали свідчили про значну розвиненість із зазначених типів батьківського ставлення. Проте виокремлено сім'ї, які не мають чітко вираженого типу батьківського ставлення. 3 огляду на це виокремлено змішані типи, такі як «кооперація-симбіоз» «кооперація-гіперсоціалізація». Тип батьківського ставлення «кооперація-симбіоз» виявлено у двох сім'ях, що мають дітей із нормо-типовим розвитком, та у чотирьох сім'ях із дітьми з порушеннями психофізичного розвитку. Такий тип «кооперація-гіперсоціалізація» виявлено у двох сім'ях що виховують дітей із нормо-типовим розвитком.
Висновки 3 проведеного дослідження. Для сприятливого розвитку дитини 3 порушеннями психофізичного розвитку потрібно, щоб її любили, приймали такою, якою вона $€$, та відносились 3 повагою. Ставлення до дитини є одним із складників дитячо-батьківських відносин. За нашими результати, домінуючим типом для сімей, що виховують дітей із порушеннями психофізичного розвитку, $€$ «кооперація». Отже, такі батьки добре розуміють і знають, чого потребує їхня дитина, проявляють зацікавленість у справах їхніх дітей. Вони відчувають позитивні емоції до своїх дітей. А це позитивно впливає на її розвиток.

\section{ЛІТЕРАТУРА:}

1. Андрейко Б В. Психологічна допомога батькам дітей з порушенням розвитку. Психологія і особистість: зб. наук. праць, Інститут психології імені Г.С. Костюка НАПН України. Полтава: ПНПУ ім. В.Г. Короленка. № 2 (10), ч. 2. 2016. С. 58-64.

2. Мушкевич М.І. Типи батьківського ставлення у сім'ях, які виховують проблемних дітей. Вісник Чернігівського національного педагогічного університету. Серія Психологічні науки» / гол. ред. М.О. Носко. Чернігів : ЧНПУ, 2012. Вип. 105. Т. 2. C. 21-24.

3. Мушкевич М.І. Наукові підходи до сім'ї з проблемною дитиною. Психологічні перспективи : зб. наук. пр. Волинський національний університет ім. Лесі Українки. Луцьк, 2013. Вип. 21. С. 164-175.

4. Варга А., Столин В. Психологические тесты. Москва, 2001. С. 144-152. 